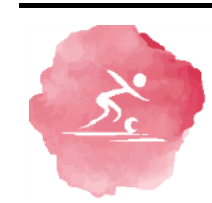

Arquivos Brasileiros de Educação Física

Brazilian Archives of Physical Education

Universidade Federal do Tocantins - UFT

Curso de Educação Física

Editorial

DOI: 10.20873/uft.2595-(0096.2018.v1n1p9

\title{
Educação Física, Saúde e Qualidade de Vida
}

Joana Marcela Sales de Lucena'

${ }^{1}$ Universidade Federal do Tocantins - UFT, Curso de Licenciatura em Educação Física, Avenida Nossa Senhora de Fátima, 1588, Centro, Tocantinópolis/Tocantins/TO. E-mail: joana.sales@mail.uft.edu.br

A Educação Física é considerada um campo vasto para crescimento científico, tamanha a abrangência de áreas e saberes fomentados todos os dias em pesquisas, ações de extensão e ensino nas Universidades e Faculdades brasileiras. Especificamente, o crescente número de manuscritos que envolvem a Educação Física na área de Saúde demonstram, expressivamente, o interesse dos pesquisadores e do público por essa vertente de estudo.

A primeira edição da Arquivos Brasileiros de Educação Física - ABEF, busca reunir estudos de revisão, resumos científicos e artigos originais que trazem a ação da Educação Física na área de saúde e, como forma descompartimentar o conhecimento, estudos que interligaram a Educação Física com a qualidade de vida, o envelhecimento, o SUS e a produção científica. Inicialmente, na sessão de resumos são apresentados trabalhos submetidos ao II Seminário Intercampus de Educação Física da Universidade Federal do Tocantins - UFT e $4^{\circ}$ Seminário Internacional sobre Novas Perspectivas do Envelhecimento Humano: Desafios do século XXI, da Universidade de Brasília - UnB. Ambos com uma visão abrangente da atuação da Educação Física no meio escolar e na área da saúde.

Os estudos que formam a primeira edição da Arquivos Brasileiros de Educação Física ABEF investigam desde a produção científica em eventos e periódicos nacionais, como também são estudos originais que realizaram investigações transversais e longitudinais de professores, idosos e pessoas com patologias específicas, demonstrando mais uma vez a abrangência da área da Educação Física e as possibilidades de atuação profissional com bases científicas.

Cada edição da Arquivos Brasileiros de Educação Física - ABEF buscará reunir estudos dentro de uma temática específica, embora seja política deste periódico manter o escopo o mais abrangente possível, em conformidade com o campo de atuação da Educação Física. Ainda, o conhecimento científico não limita-se a áreas e profissões, sendo absolutamente livre pra descobertas e melhora da vida dos seres humanos, dessa forma, a Arquivos Brasileiros de Educação Física - ABEF receberá manuscritos de outras áreas da saúde também.

A colaboração de estudantes, professores e pesquisadores é fundamental para o crescimento científico e da Arquivos Brasileiros de Educação Física - ABEF, portanto a política de qualidade deste periódico envolve o cuidado com publicações originais, revisores anti-plágio, consideração pelos aspectos éticos e prazo de resposta inferior a 30 dias úteis. Adicionalmente, a Arquivos Brasileiros de Educação Física - ABEF tem continuamente renovado seu corpo editorial científico e seu quadro de revisores para maior heterogeneidade, avaliação duplo-cega por pares e projeta a inserção de Digital Object Identifier (DOI) em seus manuscritos.

A Arquivos Brasileiros de Educação Física - ABEF agradece a confiança dos (as) autores(as) e aos(as) avaliadores(as) pelas revisões dos manuscritos apresentados neste número.

Boa leitura!!!

Como citar esse editorial:

DE LUCENA, J. M. S. Educação Física, Saúde e Qualidade de Vida. Arq. Bras. Educ. Fís., Tocantinópolis, v. 1, n. 1, p. 09, 2018.

Arquivos Brasileiros de Educação Física/Brazilian Archives of Physical Education https://sistemas.uft.edu.br/periodicos/index.php/abeducacaofisica ISSN: 2595 - 0096 | Contato: arqbef@gmail.com/ (63) 3471-6041 


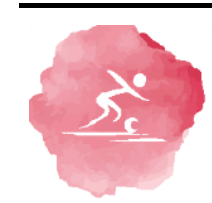

Arquivos Brasileiros de Educação Física

Brazilian Archives of Physical Education

Universidade Federal do Tocantins - UFT

Curso de Educação Física

Editorial

DOI: 10.20873/uft.2595-(0096.2018.v1n1p9

\section{Physical Education, Health and Quality of Life}

Joana Marcela Sales de Lucena ${ }^{1}$

${ }^{1}$ Universidade Federal do Tocantins - UFT, Degree in Physical Education, Avenida Nossa Senhora de Fátima, 1588, Centro, Tocantinópolis / Tocantins / TO. E-mail: joana.sales@mail.uft.edu.br

Physical Education is considered a vast field for scientific growth, such as the range of areas and knowledge fostered every day in research, extension and teaching activities in Brazilian Universities and Colleges. Specifically, the increasing number of manuscripts that involve Physical Education in the Health area expressly expresses the interest of researchers and the public in this study.

The first edition of the Brazilian Archives of Physical Education - ABEF, seeks to gather review studies, scientific summaries and original articles that bring the action of Physical Education in the health area and, as a way to uncover knowledge, studies that have linked Physical Education with quality of life, aging, SUS and scientific production. Initially, the abstracts session presents papers submitted to the II Intercampus Seminar of Physical Education of the Federal University of Tocantins - UFT and 4th International Seminar on New Perspectives of Human Aging: Challenges of the 21st Century, University of Brasilia - UnB. Both with a comprehensive view of the performance of Physical Education in the school environment and in the health area.

The studies that form the first edition of the Brazilian Archives of Physical Education $\mathrm{ABEF}$ investigate from the scientific production in national events and journals, as well as original studies that carried out cross-sectional and longitudinal investigations of teachers, elderly and people with specific pathologies, demonstrating yet another the scope of the Physical Education area and the possibilities of professional action with scientific bases.

Each edition of the Brazilian Archives of Physical Education - ABEF will seek to gather studies within a specific theme, although it is the policy of this journal to keep the scope as wide as possible, in accordance with the field of Physical Education. Also, scientific knowledge is not limited to areas and professions, being absolutely free to discover and improve the lives of human beings, so, the Brazilian Archives of Physical Education - ABEF will receive manuscripts from other areas of health as well.

The collaboration of students, professors and researchers is fundamental for the scientific growth and the Brazilian Archives of Physical Education - ABEF, therefore the quality policy of this journal involves the care with original publications, anti-plagiarism reviewers, consideration for the ethical aspects and term of less than 30 business days. In addition, the Brazilian Archives of Physical Education (ABEF) has continually renewed its scientific editorial staff and its panel of reviewers for greater heterogeneity, double-blind peer evaluation, and projects the insertion of the Digital Object Identifier (DOI) into its manuscripts.

The Brazilian Archives of Physical Education - ABEF thanks the confidence of the authors and the evaluators for the revisions of the manuscripts presented in this issue.

Good reading!!!

How to cite this editorial:

DE LUCENA, J. M. S. Physical Education, Health and Quality of Life. Arq. Bras. Educ. Fís., Tocantinópolis, v. 1, n. 1, p. 09, 2018. 